\title{
Context-Dependent Biodiversity Conservation Management Regimes
}

\author{
Heidi Gjertsen and Christopher B. Barrett*
}

May 2000 Draft

Comments greatly appreciated

*The authors are Graduate Student and Associate Professor, respectively, Department of Agricultural, Resource, and Managerial Economics, Cornell University. Special thanks to Diji Chandrasekharan Behr for helpful comments.

(C) Copyright 2000 by Heidi Gjertsen and Christopher B. Barrett. All rights reserved. Readers may make verbatim copies of this document for non-commercial purposes by any means, provided that this copyright notice appears on all such copies. 


\section{Introduction}

When individuals lack incentive to consider the benefits that accrue to others from the existence of a common pool resource such as a fish stock, or a public good such as biodiversity, they commonly overexploit the natural resource base. The core challenge in this context, and of environmental conservation in general, is to align individual and social incentives, thereby correcting what economists term the "externalities" problem. Garrett Hardin famously termed this overexploitation of open access resources "the tragedy of the commons" (Hardin, 1968). Since then, much effort has been mounted towards identifying institutions that can change incentives for overexploitation and thereby eliminate the externality problem.

Initially, the solution was to turn resources over to the state, which would presumably manage these resources for the public good. Protected areas and national parks have a long history of fairly successful conservation in wealthier countries such as the United States and Canada, as well as in some middle income countries such as South Africa. These models were applied to tropical areas throughout the 1950s to 1970s, but have commonly failed to conserve biodiversity, often due to the conflicts created between those protecting the park and those requiring use of resources within the park.

The perceived failure of this state-directed "fences and fines" approach to tropical biodiversity conservation has prompted experimentation with a number of alternative approaches (Wells and Brandon, 1992). In particular, various forms of community-based natural resource management (CBNRM) and co-management are being hailed by many as "win-win" situations that meet the needs of both wildlife and human populations and prevent the loss of biodiversity (Getz et al., 1999; Western and Wright, 1992). The state-directed approach commonly disregarded the ability of some communities to manage resource use effectively, thereby 
destroying some functioning traditional management systems (Berkes and Folke, 1998; Ostrom, 1990). This recognition led to a flurry of writing about successful cases of collective action, which has in turn fed the current fashion of decentralization and devolution of resource management authority to community groups. Community-based conservation strategies proceed from the assumptions that local people have intimate knowledge about their environment and if they are given authority over their own resources, they will better protect them. Most international development agencies and conservation organizations now fund "community based management" or "co-management" projects. For example, more than $1 / 3$ of all current World Bank-GEF biodiversity conservation projects include community involvement in management, local participation, or community sustainable resource use as one of their goals (World Bank, 2000). Despite the appeal of community-based and co-management schemes, numerous case studies suggest that their effectiveness in conserving biodiversity is far from uniform and seems to depend heavily on the biophysical and socioeconomic context of conservation.

Some researchers question the utility of the search for a single, optimal institutional design for conservation and ask whether different arrangements are perhaps appropriate for different settings (Barrett et al., 1999; Ostrom et al., 1999; Hobley, 1996). To date, however, there has been little analytical work that explores how key variables interact and determine when one arrangement will be more effective than another. Empirical work has been mostly descriptive, with little analytical, much less prescriptive content. Particular case studies consider different factors that affect the success of a conservation approach, thus comparison of cases and testing of hypotheses is difficult, if not impossible (Rasmussen and Meinzen-Dick, 1995). Furthermore, context-specific institutional design can be politically unappealing. Mary Hobley writes: 
As Ostrom (1994) so cogently argues, it is not an either/or situation but an 'and' situation where there are many arrangements that can be accommodated ranging from partnerships between government and local people to complete local control. Using this notion of a continuum there are a variety of institutional arrangements that could be selected according to the particular context. This approach requires site specificity and a high degree of social contextual understanding from the implementing or facilitating organisation. To date, although appealing to academics in its recognition of complexity and diversity, it has been resisted by government institutions used to the prescriptive model-based approach to development. (Hobley, 1996; p.100)

Some valuable work exists on design principles for particular conservation institutions. For example, Ostrom's principles for successful small-scale common pool resource institutions are well-known (Ostrom, 1990). Others have proposed conditions for successful protected areas or community-based management schemes (Brandon et al., 1998; Hobley, 1996). It is unclear in these analyses, however, whether the conditions are necessary or sufficient, whether there is a prioritization of conditions (i.e. can conditions be ranked in terms of their relative impact on success), and whether failure to meet some of the conditions suggests the need for strengthening these aspects, or a different management approach altogether. A general theory to explain what works where and why would help practitioners in choosing appropriate conservation designs.

This paper adapts models from the agrarian contracts literature to offer a predictive theory of optimal conservation design, in terms of locating authority for specific conservation tasks, as a function of prevailing biophysical, economic, and sociopolitical conditions (Eswaran and Kotwal, 1985). The purpose of this paper is to illustrate how different contextual conditions may affect which type of institutional design will be most appropriate, and to provide a theoretical framework for beginning to consider these questions in a more rigorous fashion. 


\section{The Model}

The basic problem of conservation revolves around two issues, (i) the existence of multiple tasks necessary to conserve a natural resource (e.g., resource mobilization, rule enforcement), and (ii) externalities surrounding each of the several activities involved in resource conservation or exploitation. Conservation is not a single act, but a suite of tasks demanding different sets of skills. Who should perform a given task depends, according to the principle of comparative advantage, on agents' relative ability for conducting that activity, which may be conditioned by other exogenous factors (e.g., skill or resource endowments). Just as conservation agents must, collectively if not always individually, perform multiple tasks, so do they have objectives that transcend a unitary focus on conservation. Parties evince different degrees of care about conservation, whether for intrinsic or instrumental reasons. Successful institutional designs for conservation must take into account both differences in parties' interest in conservation and differences in their abilities to undertake the tasks necessary to conserve a resource. Underlying variation in the biophysical, economic, or sociopolitical context can affect these factors, inducing variation in the optimal institutional design of conservation.

For the purposes of simplifying a terribly complex reality into a tractable model that highlights the key relationships at play, we consider the case of two agents who must, in some combination, perform two different conservation-related tasks. The agents in the model are "government" and "community." Government refers to the national government and community refers to a unitary composite of a collection of individuals who extract resources from the ecosystem at stake. Although this categorization is a gross oversimplification of socio-politicalcultural reality, it will be adequate to illustrate some basic points. Both community and government welfare vary directly with the state of the ecosystem's health. 
We similarly reduce the many tasks involved in conservation to two: financing and management. Conservation financing generates funds necessary to cover the costs of conservation activities, preferably from those who benefit from conservation of the ecosystem at stake, i.e. by internalizing the positive externalities associated with conservation. It could also refer to nonfinancial contributions such as scientific expertise and training. Management refers to making and enforcing the rules that govern resource use so as to maintain or improve the ecosystem, especially by internalizing the negative externalities associated with resource exploitation. Both these actions are consume scarce resources that could be allocated to other desirable activities, so each party would rather the other incur the costs of conservation. Although the method of managing and enforcing, i.e. the type of rules and how they are enforced, is of great importance, we abstract from that choice in this paper. In this case, we are only concerned with who performs the task, and not with the instrument(s) they use. We model this as a labor allocation problem, subject to a time constraint, although it could equally be recast as a general resource allocation problem.

We assume the government is at least as efficient than community in fundraising, due to its coercive powers of taxation and its superior access to external donors. The community, meanwhile, is at least as efficient than government in management, due to proximity to the resource, superior information about individual users' activities and the condition of the ecosystem, and lower cost opportunities to sanction undesirable behaviors. The relative importance of this pattern of comparative advantage is conditioned by exogenous factors (which we assume, without loss of generality, to take values between 0 and 1 , except for $\rho$ which ranges from 1 to infinity), such as the scale of the externality, $\rho$ (to what degree conservation of the resource yields benefits to people outside of the community), the size of the ecosystem, $\eta$, 
community instability, $\sigma$ (weakness of leadership, excessive immigration/emigration, lack of traditional ties, etc.), and government undependability, $\mu$ (degree to which outsiders believe government will not use funds for their stated purposes). These variables have been deemed relevant to the success of community management by a number of studies (Rasmussen and Meinzen-Dick, 1995).

We make the following additional, simplifying assumptions: As the scale of the externality increases, both community and government ability in raising funds increases. The more outsiders benefit from conservation, the more funds they are willing to provide for this purpose, thus it will take less effort on the part of either government or community to generate these funds. We assume that community ability increases at a decreasing rate, as opposed to the government's constantly increasing ability, reflecting government's absolute advantage in inducing those outside the ecosystem to contribute to its conservation. This captures the notion that when the size of the externality is small (i.e. locals receive most of the conservation benefit), there is less of a spread between government and community efficiency in generating resources for conservation than when the size of the externality is large. Ecosystem maintenance provides benefits to both locals and outsiders. For example, Costanza et al. (1997) estimated the value of various ecosystem services, some of which may accrue mainly to locals (for example, coral reefs provide shoreline protection), and others chiefly to outsiders (for example, coral reefs provide opportunities for recreation and tourism). If the benefits of conservation flow mainly to local resource users (e.g. conserving soil and water on a farmer's plot), then government is unlikely to possess superior capacity to generate the resources necessary to conduct conservation operations. On the other hand, if the share of benefits that accrue to locals from maintaining an ecosystem (e.g. preserving a large tract of biodiverse rainforest) is relatively small, then government may be 
better positioned to cover the costs of conserving this ecosystem. The important point is that government's superior capacity to generate external resources for conservation matters more the greater the positive externality associated with the health of the ecosystem under study. As the size of the ecosystem increases, government management ability decreases, but to a lesser extent than community management ability, since government's jurisdiction covers a greater area than that of the community. But as government dependability decreases, perhaps due to corruption, incompetence, or political instability, government fundraising capacity declines. Similarly, as community instability increases, its capacity to make and enforce rules, and thus its management ability, decreases. Community fundraising ability thus equals $\rho^{1 / 2}$, government fundraising ability equals $\rho / \mu$, community management ability equals $1 / \sigma \eta$, and government management ability equals $1 / \eta^{1 / 2}$.

In what follows, it will be useful to think of government and community ability in the two conservation tasks as relative efficiencies. Government is at least as efficient as community in fundraising: one hour of community fundraising time is equivalent to only a fraction, $\left(\rho^{1 / 2}\right) /$ $(\rho / \mu)$, of government fundraising time. Community is at least as efficient as government in managing: one hour of government management time is equivalent to only a fraction, $\left(1 / \eta^{1 / 2}\right)$ / $(1 / \sigma \eta)$, of community management time. Community relative fundraising efficiency thus equals $\mu / \rho^{1 / 2}$, and government relative management efficiency equals $\sigma \eta^{1 / 2}$. Government fundraising efficiency and community management efficiency are normalized to 1 .

The state of the ecosystem, E, is defined by the following function, which depends in part on the (labor) resources applied to each of our two stylized conservation tasks:

$$
\mathrm{E}_{\mathrm{t}}=\mathrm{E}_{\mathrm{t}-1}\left(\mathrm{~L}^{\mathrm{f}} \mathrm{L}^{\mathrm{m}} / \mathrm{L}_{\mathrm{c}}^{\mathrm{d}}\right)
$$


where $E_{t}$ is the present state of the ecosystem, $E_{t-1}$ is the state of the ecosystem last period, $L^{f}$ is effective community or government fundraising labor $\left(\left(\mu / \rho^{1 / 2}\right) L_{c}{ }^{f}\right.$ and $L_{g}{ }^{f}$, respectively), $\mathrm{L}^{\mathrm{m}}$ is community or government management labor $\left(\mathrm{L}_{\mathrm{c}}{ }^{\mathrm{m}}\right.$ and $\sigma \eta^{1 / 2} \mathrm{~L}_{\mathrm{g}} \mathrm{m}$, respectively), and $\mathrm{L}_{c}{ }^{d}$ is community resource-extractive labor.

This simple representation of the "ecosystem", with constant rates of change in each variable, is the most parsimonious representation that maintains the key properties that labor allocated to fundraising or management improves the state of the ecosystem, while labor allocated to resource extraction decreases ecosystem quality. We assume a fixed proportions "production" technology so that changes in E can be readily measured in units of labor.

Besides allocating labor effort to conservation tasks, the community uses labor in income-generating activities, $\mathrm{L}_{c}{ }^{d}$ (resource-extractive labor), and $\mathrm{L}_{c}{ }^{\mathrm{n}}$ (non-extractive labor). Nonextractive labor generates a wage, $\mathrm{w}_{\mathrm{n}}$, and extractive labor generates a product, $\mathrm{D}$ (fish, for example), which can be sold in the market at price $\mathrm{p}_{\mathrm{d}}$.

The production function for the extractive product is:

$D=E^{\alpha} L_{c}^{d \beta} \quad$ where $0<\alpha, \beta<1, \beta>\alpha$

The production function is concave in both inputs, thus both ecosystem quality and resource-extractive labor increase production at a decreasing rate, i.e. there are diminishing marginal returns to labor. As ecosystem quality is improved, there are more fish in the lake, for example, and less labor is required for a given level of production. Labor inputs increase production by more than do ecosystem "inputs". We assume the marginal product of labor is increasing in ecosystem quality $\left(\partial^{2} \mathrm{D} / \partial \mathrm{L}_{\mathrm{c}}{ }^{\mathrm{d}} \partial \mathrm{E}>0\right)$, so if government expends resources on conservation, this increases the community's incentive to allocate labor to extractive production at the margin. 
The community's objective is assumed to be income maximization, where income is ${ }^{1}$ :

$$
Y_{c}=w_{n} L_{c}^{n}+p_{d} E^{\alpha} L_{c}^{d \beta}
$$

We assume that at $\mathrm{L}_{\mathrm{c}}{ }^{\mathrm{d}}=0$, the derivative from the right hand side $\left(\beta \mathrm{p}_{\mathrm{d}} \mathrm{E}^{\alpha} \mathrm{L}_{\mathrm{c}}{ }^{\mathrm{d} \beta-1}\right)$ must be greater than $\mathrm{w}_{\mathrm{n}}$, so that the community always chooses a positive level of resource-extractive labor. Community chooses the quantities of labor that maximize its income, subject to the labor constraint:

$$
\mathrm{L}_{\mathrm{c}}=\mathrm{L}_{\mathrm{c}}{ }^{\mathrm{d}}+\mathrm{L}_{\mathrm{c}}{ }^{\mathrm{n}}+\mathrm{L}_{\mathrm{c}}{ }^{\mathrm{f}}+\mathrm{L}_{\mathrm{c}}{ }^{\mathrm{m}} \quad \text { where } \mathrm{L}_{\mathrm{c}} \text { is total labor time }
$$

This captures the essence of the community's management challenge. Given its finite resources on the one hand, and its dependence on the natural resource stock, on the other, is the community best-served by expending scarce resources on various conservation tasks, or can it be better served by leaving this to others or partnering with others by sharing responsibility and authority.

Government provides labor for conservation tasks and labor, $\mathrm{L}_{\mathrm{g}}{ }^{\circ}$, for other government services. We assume it has a limited amount of labor, $\mathrm{L}_{\mathrm{g}}$, which is defined by its budget constraint. Government "welfare", which may represent its perceived responsibility to its constituency, is defined as

$$
\mathrm{W}_{\mathrm{g}}=\mathrm{AE}^{\chi}+\mathrm{BL}_{\mathrm{g}}{ }^{\mathrm{o}} \quad \text { where } \mathrm{A}>\mathrm{B}, 0<\chi<1
$$

We assume a fixed proportions production technology for government services so that provision of government services can be adequately modeled through the choice of $\mathrm{Lg}_{\mathrm{g}}^{\mathrm{o}}$. Obviously, our specification of government welfare disregards the politics inherent in government decisions of what activities it values. Governments have different objectives and different preferences, and these change over time. Any collective choice, however, can be

\footnotetext{
${ }^{1}$ We abstract from other potential community values, for tractability of the model.
} 
represented in its reduced form, and our objective function could represent a variety of government preferences. For example, $\chi$ represents government's relative preference for ecosystem services, the value of which could vary across periods or regimes.

Conservation occurs under one of three possible types of arrangements, or pseudocontracts, between government and community: the government performs both conservation tasks (government management), the community performs both conservation tasks (community management), or each performs the task in which they have an absolute advantage (comanagement). For tractability, we assume complete specialization in the case of co-management. Obviously in reality the contracts lie along a continuum, with many permutations involving other combinations of agents and tasks. However, these three contracts will suffice for illustrating our basic points.

The government offers one of these "contracts" to community, and the community accepts if the contract provides income at least as great as their reservation income, $\ddot{Y}_{c}$. The government knows the community's objective function and offers the contract that maximizes its own welfare, subject to the community receiving income equal to $\ddot{Y}_{c} .{ }^{2}$ Note that this constraint does not bind for government management, since the community is not contributing any labor to conservation activities under that particular arrangement.

The familiar solution technique in such settings is to derive the offeree's best response function and then to solve the offerer's optimal contract offer conditional on that known best response. So the first step in solving this particular model is to solve the community's income maximization problem, subject to its labor constraint and obtain optimal community labor

\footnotetext{
${ }^{2}$ Objections have been raised to this principal-agent framework in agrarian contracts models, in that it assumes the agent has no bargaining power to increase its share of the gains from contracting, see for example Bell, 1989. Although our framework could be extended to a bargaining model, in this paper we are simply concerned with the gains from contracting, and not with the distribution of these gains.
} 
allocations conditional on government labor allocations. Then we solve the government's welfare maximization problem, subject to its labor constraint and the community's optimal responses. We derive government welfare for each contract case; government will optimally choose that arrangement offering it the highest level of welfare. For ease of calculation we let $\alpha=1 / 4$ and $\beta=1 / 2$ and $\chi=1 / 2$.

Contract Option \#1: Government Management $\left(\mathrm{L}_{\mathrm{g}}{ }^{\mathrm{f}}>0, \mathrm{~L}_{\mathrm{g}}{ }^{\mathrm{m}}>0, \mathrm{~L}_{\mathrm{c}}{ }^{\mathrm{f}}=0, \mathrm{~L}_{\mathrm{c}}{ }^{\mathrm{m}}=0\right)$

Under this contract, the community's income maximization problem becomes:

$$
\begin{array}{ll}
\operatorname{Max} Y_{c}=w_{n} L_{c}{ }^{n}+p_{d} E^{1 / 4} L_{c}{ }^{d 1 / 2} & \\
& \text { s.t. } \quad \begin{array}{ll} 
& L_{c}=L_{c}{ }^{d}+L_{c}{ }^{n} \\
& E_{t}=E_{t-1}\left(L_{g}{ }^{f}\left(\sigma \eta^{1 / 2}\right) L_{g}{ }^{m} / L_{c}{ }^{d}\right)
\end{array}
\end{array}
$$

Solution of the first order necessary conditions yields community optimal labor allocations and maximal community income under government management.

$$
\begin{aligned}
& \mathrm{L}_{\mathrm{c}}{ }^{\mathrm{d}} *=\left(\mathrm{p}_{\mathrm{d}}{ }^{4} \mathrm{E}_{\mathrm{t}-1} \mathrm{~L}_{\mathrm{g}}{ }^{\mathrm{f}^{*}}\left(\sigma \eta^{1 / 2}\right) \mathrm{L}_{\mathrm{g}} \mathrm{m}^{*} / 256 \mathrm{w}_{\mathrm{n}}{ }^{4}\right)^{1 / 3} \\
& \mathrm{~L}_{\mathrm{c}}{ }^{{ }^{*}}=\mathrm{L}_{\mathrm{c}}-\left(\mathrm{p}_{\mathrm{d}}{ }^{4} \mathrm{E}_{\mathrm{t}-1} \mathrm{~L}_{\mathrm{g}}{ }^{\mathrm{f}^{*}}\left(\sigma \eta^{1 / 2}\right) \mathrm{L}_{\mathrm{g}} \mathrm{m}^{*} / 256 \mathrm{w}_{\mathrm{n}}{ }^{4 / 3}\right. \\
& \mathrm{Y}_{\mathrm{c}}{ }^{*}=\mathrm{w}_{\mathrm{n}} \mathrm{L}_{\mathrm{c}}+3\left(\mathrm{p}_{\mathrm{d}}{ }^{4} \mathrm{E}_{\mathrm{t}-1} \mathrm{~L}_{\mathrm{g}}{ }^{* *}\left(\sigma \eta^{1 / 2}\right) \mathrm{L}_{\mathrm{g}} \mathrm{m}^{*} / 256 \mathrm{w}_{\mathrm{n}}\right)^{4 / 3}
\end{aligned}
$$

Knowing this best-response labor allocation rule, government then solves its own welfare maximization problem:

$$
\begin{aligned}
& \mathrm{W}_{\mathrm{g}}=\mathrm{AE}^{1 / 2}+\mathrm{BL}_{\mathrm{g}}^{\mathrm{o}} \\
& \\
& \text { s.t. } \quad \begin{array}{ll}
\mathrm{E}_{\mathrm{t}}=\mathrm{E}_{\mathrm{t}-1}\left(\mathrm{Lg}_{\mathrm{g}}^{\mathrm{f}} \sigma \eta^{1 / 2} \mathrm{Lg}_{\mathrm{g}}^{\mathrm{m}} / \mathrm{L}_{\mathrm{c}}{ }^{\mathrm{d}}\right) \\
& \mathrm{Lg}_{\mathrm{g}}=\mathrm{L}_{\mathrm{g}}^{\mathrm{f}}+\mathrm{Lg}_{\mathrm{g}}^{\mathrm{d}}+\mathrm{L}_{\mathrm{g}}
\end{array}
\end{aligned}
$$


Solution of the first order necessary conditions yields government optimal labor allocations and maximal welfare under government management.

$$
\begin{aligned}
& \mathrm{L}_{\mathrm{g}}^{\mathrm{f}_{*}}=16 \mathrm{~A}^{3}\left(\sigma \eta^{1 / 2}\right) \mathrm{E}_{\mathrm{t}-1} \mathrm{w}_{\mathrm{n}}{ }^{2} / 27 \mathrm{p}_{\mathrm{d}}{ }^{2} \mathrm{~B}^{3} \\
& \mathrm{~L}_{\mathrm{g}}{ }^{\mathrm{m}_{*}}=16 \mathrm{~A}^{3}\left(\sigma \eta^{1 / 2}\right) \mathrm{E}_{\mathrm{t}-1} \mathrm{w}_{\mathrm{n}}{ }^{2} / 27 \mathrm{p}_{\mathrm{d}}{ }^{2} \mathrm{~B}^{3} \\
& \mathrm{~L}_{\mathrm{g}}{ }^{\mathrm{o}} *=\mathrm{L}_{\mathrm{g}}-\left(32 \mathrm{~A}^{3}\left(\sigma \eta^{1 / 2}\right) \mathrm{E}_{\mathrm{t}-1 \mathrm{w}_{\mathrm{n}}}{ }^{2} / 27 \mathrm{p}_{\mathrm{d}}{ }^{2} \mathrm{~B}^{3}\right) \\
& \mathrm{W}_{\mathrm{g}}{ }^{*}=16 \mathrm{~A}^{3} \mathrm{w}_{\mathrm{n}}{ }^{2} \mathrm{E}_{\mathrm{t}-1}\left(\sigma \eta^{1 / 2}\right) / 27 \mathrm{~B}^{2} \mathrm{p}_{\mathrm{d}}{ }^{2}+\mathrm{BL}_{\mathrm{g}}
\end{aligned}
$$

Once we have repeated this exercise for the other two prospective arrangements, we can compare $\mathrm{W}_{\mathrm{g}}{ }^{*}$ under each arrangement to establish which conservation contract best serves government's interests.

\section{Contract Option \#2: Community Management $\left(\mathrm{L}_{\mathrm{g}}{ }_{\mathrm{f}}=0, \mathrm{~L}_{\mathrm{g}}{ }^{\mathrm{m}}=0, \mathrm{~L}_{\mathrm{c}}{ }^{\mathrm{f}}>0, \mathrm{~L}_{\mathrm{c}}{ }^{\mathrm{m}}>0\right)$}

If the government offers the community this contract, then the community's income maximization problem can be represented as:

$$
\begin{aligned}
& \operatorname{Max} Y_{c}=w_{n} L_{c}{ }^{n}+p_{d} E^{1 / 4} L_{c}{ }^{d 1 / 2} \\
& \text { s.t. } \quad \begin{array}{l}
L_{c}=L_{c}{ }^{d}+L_{c}{ }^{n}+L_{c}{ }^{f}+L_{c}{ }^{m} \\
\\
E_{t}=E_{t-1}\left(\left(\mu / \rho^{1 / 2}\right) L_{c}{ }^{f} L_{c}{ }^{m} / L_{c}{ }^{d}\right)
\end{array}
\end{aligned}
$$

Solution of the first order necessary conditions yields community optimal labor allocations and maximal income under community management.

$$
\begin{aligned}
& \mathrm{L}_{\mathrm{c}}{ }^{\mathrm{d} *}=\mathrm{p}_{\mathrm{d}}{ }^{4} \mathrm{E}_{\mathrm{t}-1}\left(\mu / \rho^{1 / 2}\right) / 256 \mathrm{w}_{\mathrm{n}}{ }^{4} \\
& \mathrm{~L}_{\mathrm{c}}{ }^{{ }^{n} *}=\mathrm{L}_{\mathrm{c}}-\left(3 \mathrm{p}_{\mathrm{d}}{ }^{4} \mathrm{E}_{\mathrm{t}-1}\left(\mu / \rho^{1 / 2}\right) / 256 \mathrm{w}_{\mathrm{n}}{ }^{4}\right) \\
& \mathrm{L}_{\mathrm{c}}{ }^{\mathrm{f}_{*}}=\mathrm{p}_{\mathrm{d}}{ }^{4} \mathrm{E}_{\mathrm{t}-1}\left(\mu / \rho^{1 / 2}\right) / 256 \mathrm{w}_{\mathrm{n}}{ }^{4}
\end{aligned}
$$




$$
\begin{aligned}
& \mathrm{L}_{\mathrm{c}}{ }^{\mathrm{m}^{*}}=\mathrm{p}_{\mathrm{d}}{ }^{4} \mathrm{E}_{\mathrm{t}-1}\left(\mu / \rho^{1 / 2}\right) / 256 \mathrm{w}_{\mathrm{n}}{ }^{4} \\
& \mathrm{Y}_{\mathrm{c}}{ }^{*}=\left(256 \mathrm{w}_{\mathrm{n}}{ }^{4} \mathrm{p}_{\mathrm{e}} \mathrm{L}_{\mathrm{c}}+\mathrm{p}_{\mathrm{d}}{ }^{4} \mathrm{E}_{\mathrm{t}-1}\left(\mu / \rho^{1 / 2}\right)\right) / 256 \mathrm{w}_{\mathrm{n}}{ }^{3}
\end{aligned}
$$

Government uses the community's known optimal choice of $\mathrm{L}_{\mathrm{c}}^{\mathrm{d}^{*}}, \mathrm{~L}_{\mathrm{c}}{ }^{\mathrm{f}^{*}}$, and $\mathrm{L}_{\mathrm{c}}{ }^{\mathrm{m}^{*}}$ to solve its own welfare maximization problem:

$$
\begin{aligned}
& \mathrm{W}_{\mathrm{g}}=\mathrm{AE}^{1 / 2}+\mathrm{BL}_{\mathrm{g}}^{\mathrm{o}} \\
& \text { s.t. } \quad E_{t}=E_{t-1}\left(\left(\mu / \rho^{1 / 2}\right) L_{c}{ }_{c}^{f} L_{c}{ }^{m} / L_{c}{ }^{d}\right) \\
& \mathrm{L}_{\mathrm{g}}=\mathrm{L}_{\mathrm{g}}{ }^{\mathrm{o}} \\
& \mathrm{Y}_{\mathrm{c}}^{*} \geq \ddot{\mathrm{Y}}_{\mathrm{c}}
\end{aligned}
$$

Solution of the first order necessary conditions yields government optimal labor allocations and maximal welfare under community management.

$$
\begin{aligned}
& \mathrm{L}_{\mathrm{g}}{ }^{\mathrm{o}}=\mathrm{L}_{\mathrm{g}} \\
& \left.\mathrm{W}_{\mathrm{g}}{ }^{*}=\mathrm{Ap}_{\mathrm{d}}{ }^{2} \mathrm{E}_{\mathrm{t}-1} \mu / \rho^{1 / 2}\right) / 16 \mathrm{w}_{\mathrm{n}}{ }^{2}+B \mathrm{~L}_{\mathrm{g}}
\end{aligned}
$$

As is apparent from quick comparison, there is no unambiguous ordering possible among the maximal government welfare attainable under each of the first two contracts.

Contract Option \#3: Co-Management $\left(\mathrm{L}_{\mathrm{g}}{ }^{\mathrm{f}}>0, \mathrm{~L}_{\mathrm{g}}{ }^{\mathrm{m}}=0, \mathrm{~L}_{\mathrm{c}}{ }_{\mathrm{f}}=0, \mathrm{~L}_{\mathrm{c}}{ }^{\mathrm{m}}>0\right)$

In this final of the three contractual options facing government, the community's problem becomes:

$$
\begin{aligned}
\operatorname{Max} Y_{c}=w_{n} L_{c}{ }^{n}+p_{d} E^{1 / 4} L_{c}{ }^{d 1 / 2} & \\
& \text { s.t. } \quad \begin{array}{ll}
L_{c}=L_{c}{ }^{d}+L_{c}{ }^{n}+L_{c}{ }^{m} \\
& E_{t}=E_{t-1}\left(L_{g}{ }^{f} L_{c}{ }^{m} / L_{c}{ }^{d}\right)
\end{array}
\end{aligned}
$$


Solution of the first order necessary conditions yields community optimal labor allocations and maximal income under co-management.

$$
\begin{aligned}
& \mathrm{L}_{\mathrm{c}}{ }^{{ }^{*} *}=\left(\mathrm{p}_{\mathrm{d}}{ }^{4} \mathrm{E}_{\mathrm{t}-1} \mathrm{~L}_{\mathrm{g}} \mathrm{f}^{*} / 256 \mathrm{w}_{\mathrm{n}}{ }^{4}\right)^{1 / 2} \\
& \mathrm{~L}_{\mathrm{c}}{ }^{\mathrm{n} *}=\mathrm{L}_{\mathrm{c}}-2\left(\mathrm{p}_{\mathrm{d}}{ }^{4} \mathrm{E}_{\mathrm{t}-1} \mathrm{~L}_{\mathrm{g}} \mathrm{f}^{*} / 256 \mathrm{w}_{\mathrm{n}}{ }^{4}\right)^{1 / 2} \\
& \mathrm{~L}_{\mathrm{c}}{ }^{{ }^{\mathrm{m}} *}=\left(\mathrm{p}_{\mathrm{d}}{ }^{4} \mathrm{E}_{\mathrm{t}-1} \mathrm{~L}_{\mathrm{g}}{ }^{\mathrm{f}^{*}} / 256 \mathrm{w}_{\mathrm{n}}{ }^{1 / 2}\right. \\
& \mathrm{Y}_{\mathrm{c}}{ }^{*}=\mathrm{w}_{\mathrm{n}} \mathrm{L}_{\mathrm{c}}+\mathrm{p}_{\mathrm{d}}{ }^{2} \mathrm{E}_{\mathrm{t}-1}{ }^{1 / 2} \mathrm{~L}_{\mathrm{g}}{ }^{\mathrm{f} * 1 / 2} / 8 \mathrm{w}_{\mathrm{n}}
\end{aligned}
$$

The government's problem and its optimal choices and maximal welfare conditional on these community best-responses are ${ }^{3}$ :

$$
\begin{gathered}
\mathrm{W}_{\mathrm{g}}=\mathrm{AE}^{1 / 2}+\mathrm{BL}_{\mathrm{g}}{ }^{\mathrm{o}} \\
\text { s.t. } \quad \begin{array}{l}
\mathrm{E}_{\mathrm{t}}=\mathrm{E}_{\mathrm{t}-1}\left(\mathrm{~L}_{\mathrm{g}}{ }^{\mathrm{f}} \mathrm{L}_{\mathrm{c}}{ }^{\mathrm{m}} / \mathrm{L}_{\mathrm{c}}{ }^{\mathrm{d}}\right) \\
\mathrm{L}_{\mathrm{g}}=\mathrm{L}_{\mathrm{g}}+\mathrm{L}_{\mathrm{g}} \\
\mathrm{Y}_{\mathrm{c}}{ }^{*} \geq \ddot{\mathrm{Y}}_{\mathrm{c}}
\end{array} \\
\mathrm{L}_{\mathrm{g}}{ }^{\mathrm{f}}=\left(64 \mathrm{w}_{\mathrm{n}}{ }^{2} / \mathrm{p}_{\mathrm{d}}{ }^{4} \mathrm{E}_{\mathrm{t}-1}\right)\left(\ddot{\mathrm{Y}}_{\mathrm{c}}-\mathrm{w}_{\mathrm{n}} \mathrm{L}_{\mathrm{c}}\right)^{2} \\
\mathrm{~L}_{\mathrm{g}}{ }^{0 *}=\mathrm{L}_{\mathrm{g}}-\left(64 \mathrm{w}_{\mathrm{n}}{ }^{2} / \mathrm{p}_{\mathrm{d}}{ }^{4} \mathrm{E}_{\mathrm{t}-1}\right)\left(\ddot{\mathrm{Y}}_{\mathrm{c}}-\mathrm{W}_{\mathrm{n}} \mathrm{L}_{\mathrm{c}}\right)^{2} \\
\mathrm{~W}_{\mathrm{g}}{ }^{*}=8 \mathrm{Aw}_{\mathrm{n}} / \mathrm{p}_{\mathrm{d}}{ }^{2}\left(\ddot{\mathrm{Y}}_{\mathrm{c}}-\mathrm{W}_{\mathrm{n}} \mathrm{L}_{\mathrm{c}}\right)+\mathrm{BL} \mathrm{g}-\left(64 \mathrm{~B} \mathrm{w}_{\mathrm{n}}{ }^{2} / \mathrm{p}_{\mathrm{d}}{ }^{4} \mathrm{E}_{\mathrm{t}-1}\right)\left(\ddot{\mathrm{Y}}_{\mathrm{c}}-\mathrm{W}_{\mathrm{n}} \mathrm{L}_{\mathrm{c}}\right)^{2}
\end{gathered}
$$

Once again, there is no unambiguous ordering available among the maximal government welfare under each of the three contracts amongst which government must choose. The optimal conservation contract depends fundamentally on the context, as captured by the model's parameters.

\footnotetext{
${ }^{3} \mathrm{We}$ assume the community incentive compatibility constraint $\left(\mathrm{Y}_{\mathrm{c}}^{*} \geq \ddot{\mathrm{Y}}_{\mathrm{c}}\right)$ binds with equality, i.e. the community is held to their reservation income.
} 


\section{Results}

Government chooses the contract that maximizes its welfare, which is an increasing function of ecosystem quality and government services. Gathering together results from the preceding section, government welfare under the three types of contracts is as follows:

\section{1. government management}

$\mathrm{W}_{\mathrm{g}}^{*}=16 \mathrm{~A}^{3} \mathrm{~W}_{\mathrm{n}}^{2} \mathrm{E}_{\mathrm{t}-1}\left(\sigma \eta^{1 / 2}\right) / 27 \mathrm{~B}^{2} \mathrm{p}_{\mathrm{d}}^{2}+\mathrm{BL}_{\mathrm{g}}$

\section{2. community management}

$\mathrm{W}_{\mathrm{g}}^{*}=\operatorname{Ap}_{\mathrm{d}}{ }^{2} \mathrm{E}_{\mathrm{t}-1}\left(\mu / \rho^{1 / 2}\right) / 16 \mathrm{w}_{\mathrm{n}}^{2}+\mathrm{BL}_{\mathrm{g}}$

\section{3. co-management}

$\mathrm{W}_{\mathrm{g}}{ }^{*}=8 \mathrm{Aw_{ \textrm {n } }} / \mathrm{p}_{\mathrm{d}}{ }^{2}\left(\ddot{\mathrm{Y}}_{\mathrm{c}}-\mathrm{w}_{\mathrm{n}} \mathrm{L}_{\mathrm{c}}\right)+\mathrm{BL}_{\mathrm{g}}-\left(64 \mathrm{Bw_{ \textrm {n } }} / \mathrm{p}_{\mathrm{d}}{ }^{4} \mathrm{E}_{\mathrm{t}-1}\right)\left(\ddot{\mathrm{Y}}_{\mathrm{c}}-\mathrm{w}_{\mathrm{n}} \mathrm{L}_{\mathrm{c}}\right)^{2}$

One can now readily determine which contract will be chosen at different relative efficiencies subject to any particular set of starting values. For what follows, we use the following base case:

$$
\mathrm{E}_{\mathrm{t}-1}=1.25, \mathrm{w}_{\mathrm{n}}=0.7, \mathrm{p}_{\mathrm{d}}=1.42, \mathrm{~L}_{\mathrm{c}}=1, \mathrm{~L}_{\mathrm{g}}=1, \ddot{\mathrm{Y}}_{\mathrm{c}}=1.2, \mathrm{~A}=0.5, \mathrm{~B}=0.4
$$

One key point we wish to make is that the optimal contract turns fundamentally on the relative efficiency of each party in the two constituent tasks necessary for successful conservation. This can be depicted graphically, as in Figure 1, which partitions the relative efficiency space according to the contract type that prevails, given the base case scenario. These results are not unique to the parameter values; the general pattern obtains for all choices of 
values. What does change with different combinations of parameter values, is the switchover point between contracts, described below.

\section{Figure 1. Partitioning of relative efficiency space by optimal contract}
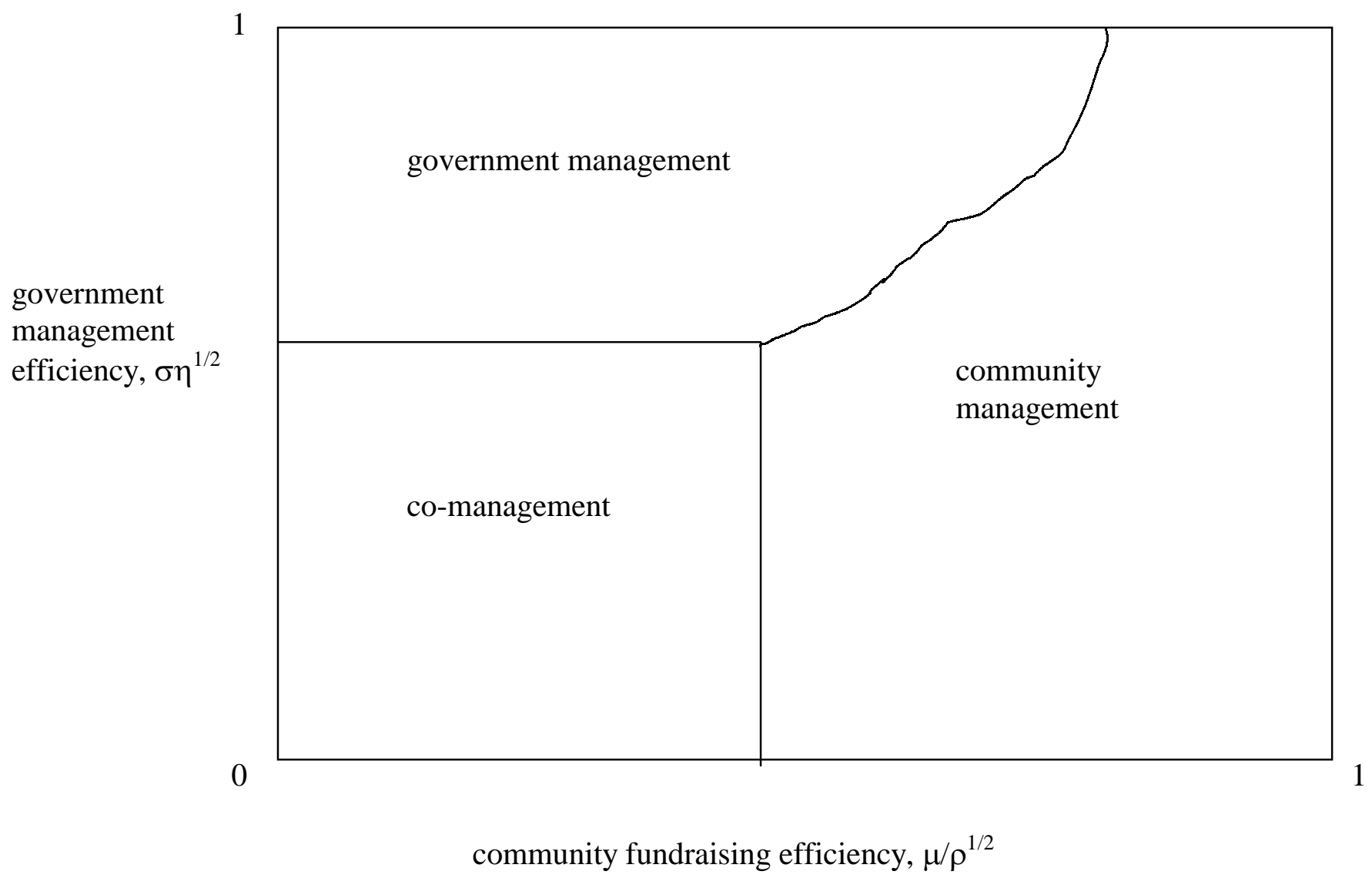

When both relative efficiency values are low, meaning there is a great difference in agent efficiency in both tasks, co-management is optimal, because specialization according to comparative advantage generates such substantial aggregate gains that it becomes optimal to organize in this way even though neither party enjoys the full benefit of its efforts, due to the positive externalities associated with ecosystem quality. This will be the case when $\mu / \rho^{1 / 2}$ is 
small and $\sigma \eta^{1 / 2}$ is small, i.e. when government credibility is high and/or the scale of the externality is large, and the size of the ecosystem is small and/or community stability is high. For example, co-management schemes are being used for the conservation of some coral reef ecosystems. A co-management scheme that is somewhat representative of our specification of co-management is the Soufrière Marine Management Area in Saint Lucia. In response to threats to reefs on the west coast of the island of St. Lucia, local fishermen, hoteliers, dive operators, government agencies, and community groups negotiated an agreement to form the Soufriere Marine Management Area. Management activities are primarily carried out by a communitybased local NGO (the Soufrière Regional Development Foundation, SRDF), with technical assistance from the Department of Fisheries. The SRDF is comprised of representatives of all major stakeholders and makes decisions about rules in the area. External funding has been provided by USAID (through the Government of St. Lucia ENCORE project), the French government and the Caribbean Conservation Association. In this case, the size of the protected ecosystem is fairly small (fringing coral reefs along $10 \mathrm{~km}$ of coastline), government credibility is fairly high, the scale of the externality is large (coral reefs provide tourism opportunities, ecosystem services, as well as local benefits such as fishing), and the community, although not necessarily homogeneous or stable, has its various interests represented by the SRDF (Pomeroy, 1999; SMMA, 2000).

Through specialization, co-management exploits the comparative advantage of each party in a given task. However, co-management will not always be optimal, due to an externality problem inherent in this approach. Since agents only consider their private return from their contribution of conservation labor, they will provide less labor than is socially optimal. Government and community both want to free ride under co-management, but since they both 
value ecosystem quality, there is a limit to their willingness to free ride. If their free riding entails enormous losses of ecosystem health (as in the case when the other party's relative efficiency equals zero), then the gains from free riding are, under the relatively mild modeling assumptions imposed, excessive relative to the costs. But as the efficiency differences between the two parties lessen and the gains from specialization decrease, then it may become optimal to move towards a system where one agent performs both tasks.

As government becomes less efficient at fundraising, i.e. $\mu / \rho^{1 / 2}$ increases, but community is still relatively efficient at managing, i.e. $\sigma \eta^{1 / 2}$ is high, community management becomes optimal. This will be the case when government credibility is low and/or the scale of the externality is small, and the size of the ecosystem is small and/or community stability is high. An example of this could be found in some community forestry schemes in Nepal. For example, the Kamal Nahar Forest User Group (FUG) in Haththipur in the Terai Region of Nepal was handed over a national forest in 1997 and made responsible for its 'development, conservation and utilisation'. Although the ownership of the forest land remains with the state, the FUG is responsible for all management of the area. Some user groups receive external funding for community forestry, but in Haththipur the village residents pay the costs of management and they feel that the benefits will eventually outweigh these costs. In this case, the size of the ecosystem is small (canal side plantation of $5.5 \mathrm{ha}$ ), the scale of the externality is small (the "forest" is of little value to anyone outside the community), government credibility is somewhat low, and community stability is fairly high (the community is fairly homogeneous and wellorganized, and in-migration is low and confined to nearby villages) (Chakraborty et al., 1997). 
As community becomes less efficient at managing, i.e. $\sigma \eta^{1 / 2}$ decreases, but government is still relatively efficient at fundraising, i.e. $\mu / \rho^{1 / 2}$ is small, government management becomes optimal. This will be the case when government credibility is high or the scale of the externality is large, and the size of the ecosystem is large and/or community stability is low. This could represent the case of the United States, for example, where the system of government managed and financed national parks has been relatively successful for ecosystem protection. In this case, government credibility is high, the scale of the externality is fairly large (national parks benefit Americans and others with recreation opportunities and ecosystem services), the size of the ecosystem is often fairly large (e.g. Yellowstone), and community stability is fairly low (there is a substantial amount of migration and a lack of general cohesion in many U.S. communities). While the basic pattern described above obtains quite generally, the point of switchover from one contract to another depends on the levels of the other parameters, i.e. on other elements of the biophysical, economic, and sociopolitical context of conservation. Thus, as the values of the parameters of the model are changed, the contract space changes from that depicted in Figure 1. So whether government management or community management or co-management is optimal depends not only on the relative efficiency of the parties in the two tasks, but also on other exogenous factors that help to define the context. We conducted simulations on the critical values and found several interesting results, which are discussed below. Note that some of these results are sensitive to the range within which the parameter of interest is varied.

We first consider a change in $\mathrm{p}_{\mathrm{d}}$, the market price of the exploited resource. At low levels of $\mathrm{p}_{\mathrm{d}}$, government management prevails. Figure 2 demonstrates this result. We see that at $\mathrm{p}_{\mathrm{d}}=1.2$, the contract space is split between government and community management, with government management covering most of the area. When $\mathrm{p}_{\mathrm{d}}$ is low, the returns to the extractive activity are 
Figure 2. Decreasing the market price of the exploited resource $\left(p_{d}=1.2\right)$

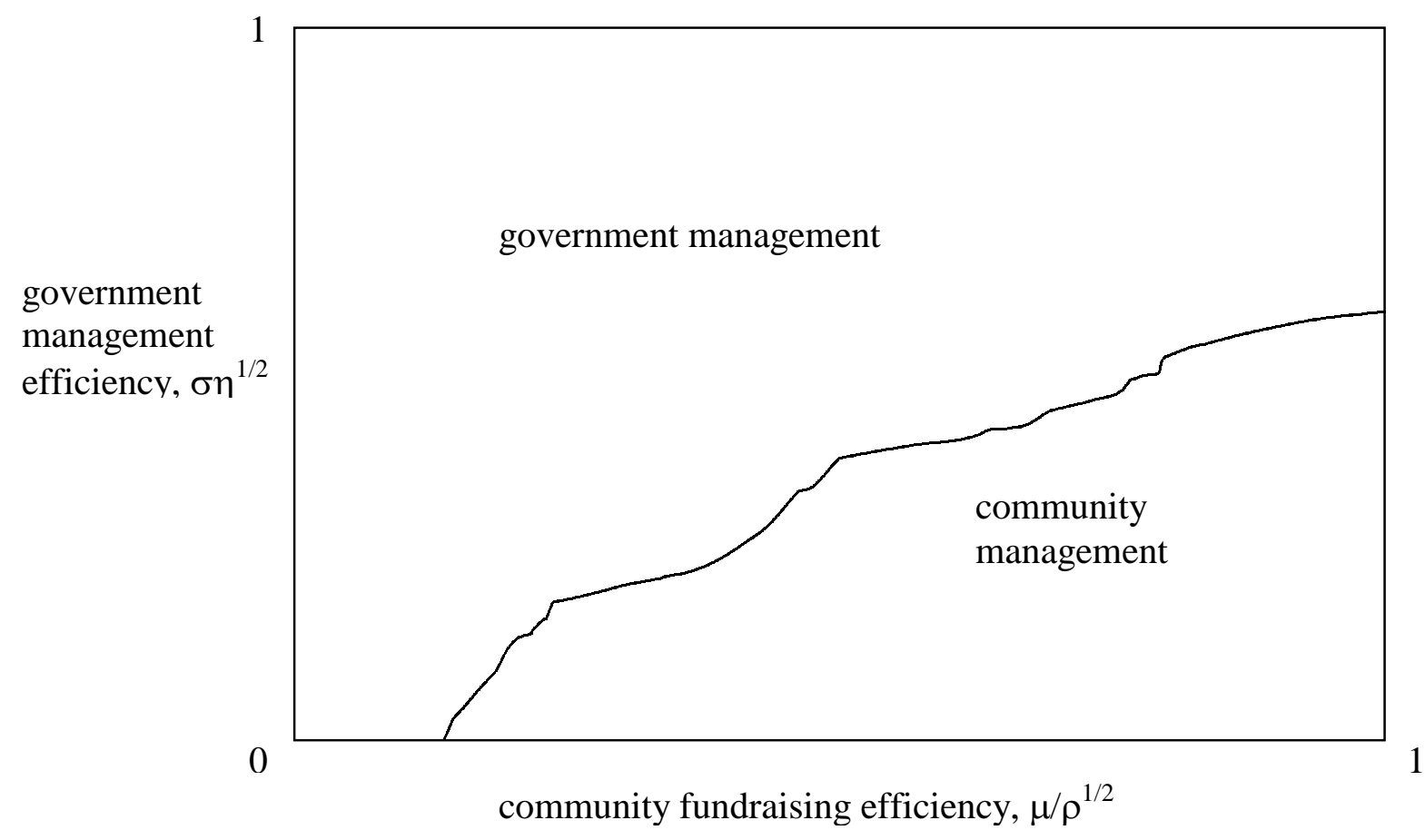

Figure 3. Increasing the market price of the exploited resource $\left(p_{d}=2.6\right)$

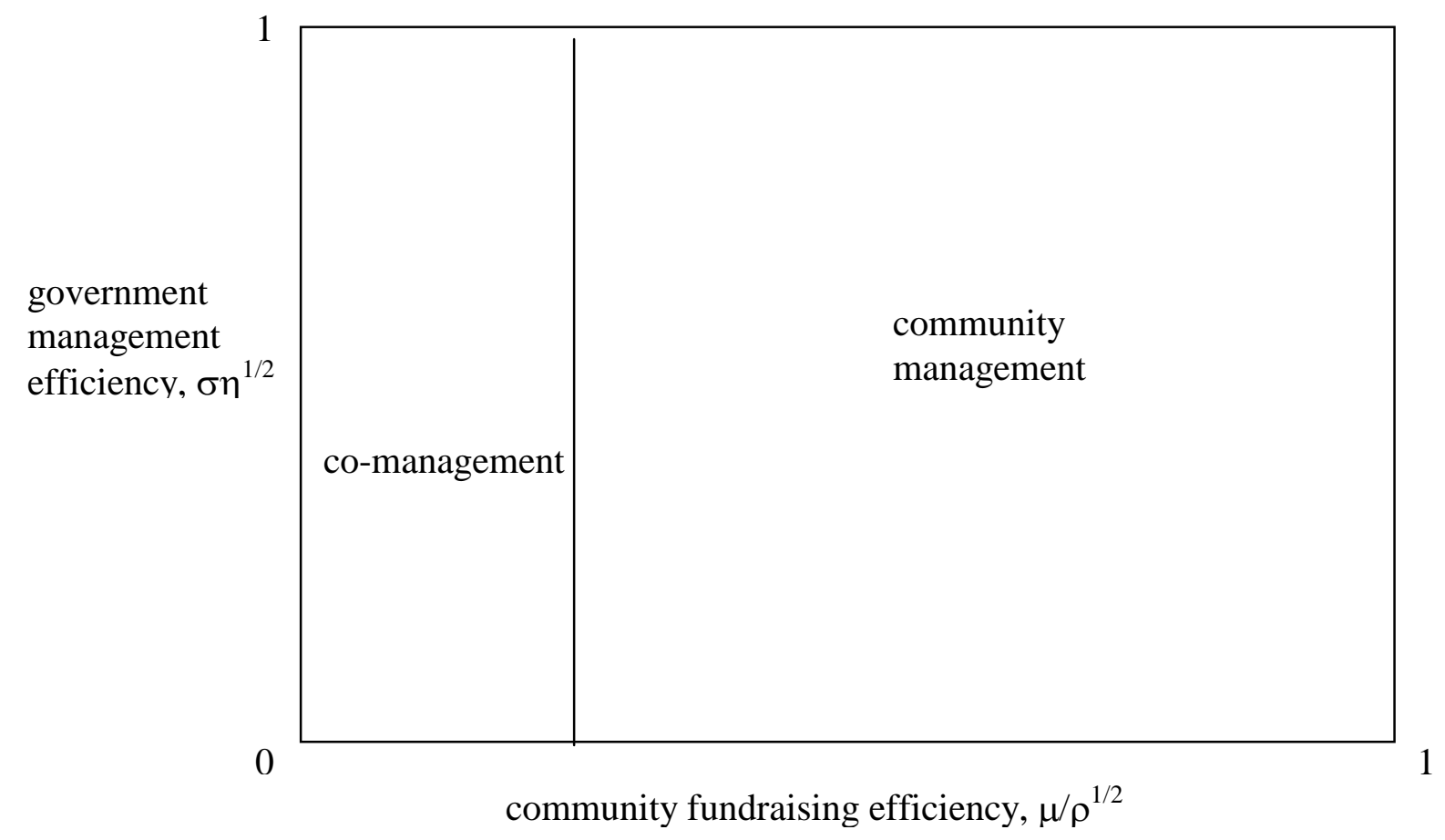


low, thus community has less of an incentive to allocate labor to improving the resource base. It instead prefers to allocate most of its labor to non-extractive activities. Thus unless community is highly efficient in management, relative to government, government chooses to perform the conservation activities itself. On the other hand, when $\mathrm{p}_{\mathrm{d}}$ rises, community has more of an incentive to manage the resource to make the most of the high return activity. Figure 3 shows how pure government management has dropped out of the picture. In this case $\left(\mathrm{p}_{\mathrm{d}}=2.6\right)$, community management and co-management cover the contract space, with community management dominating.

We next consider a change in $\mathrm{w}_{\mathrm{n}}$, the wage rate outside natural resource exploitation. At low levels of $\mathrm{w}_{\mathrm{n}}$, community management prevails. Figure 4 demonstrates this result. We see that at $\mathrm{w}_{\mathrm{n}}=0.5$, the contract space is mainly covered by community management, with some comanagement. When $\mathrm{w}_{\mathrm{n}}$ is low, community prefers to allocate its labor to resource-extractive labor, thus they will value ecosystem quality more highly (since returns to extractive labor depend positively on the state of the ecosystem) and will choose to allocate high levels of labor to conservation management and fundraising. Government thus becomes assured of a relatively high level of ecosystem quality, and they can allocate their labor to providing other services. As $\mathrm{W}_{\mathrm{n}}$ increases, however, the area covered by community management disappears and government management becomes desirable over most ranges of efficiencies, except when government is most inefficient in management. Figure 5 illustrates these results. A rising wage for nonextractive activity leads to increasing returns to non-extractive labor, thus community has less incentive to invest in the environment, since extractive labor is yielding relatively lower returns. 
Figure 4. Decreasing the wage rate for non-extractive labor $\left(w_{n}=0.5\right)$

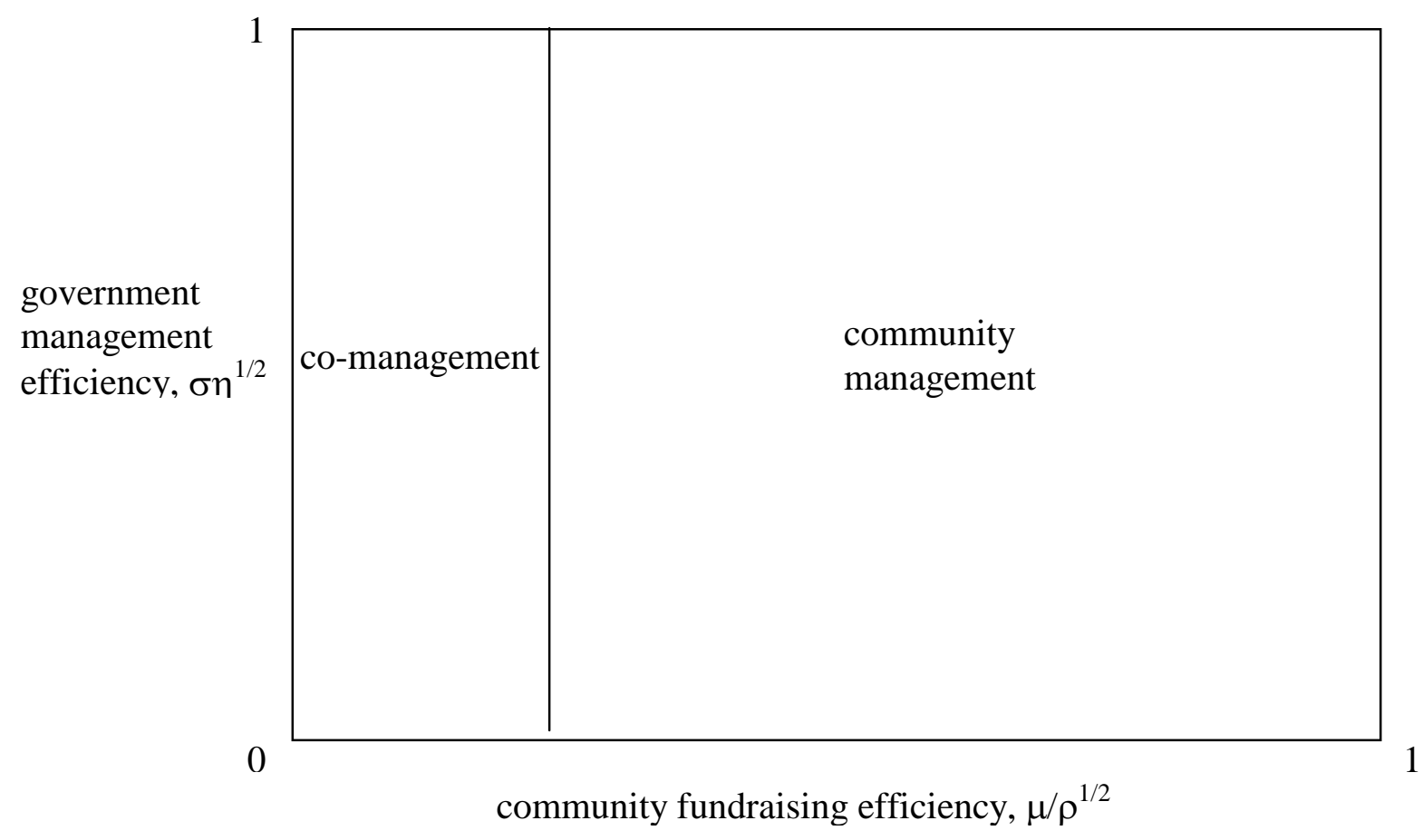

Figure 5. Increasing the wage rate for non-extractive labor $\left(w_{n}=1.15\right)$

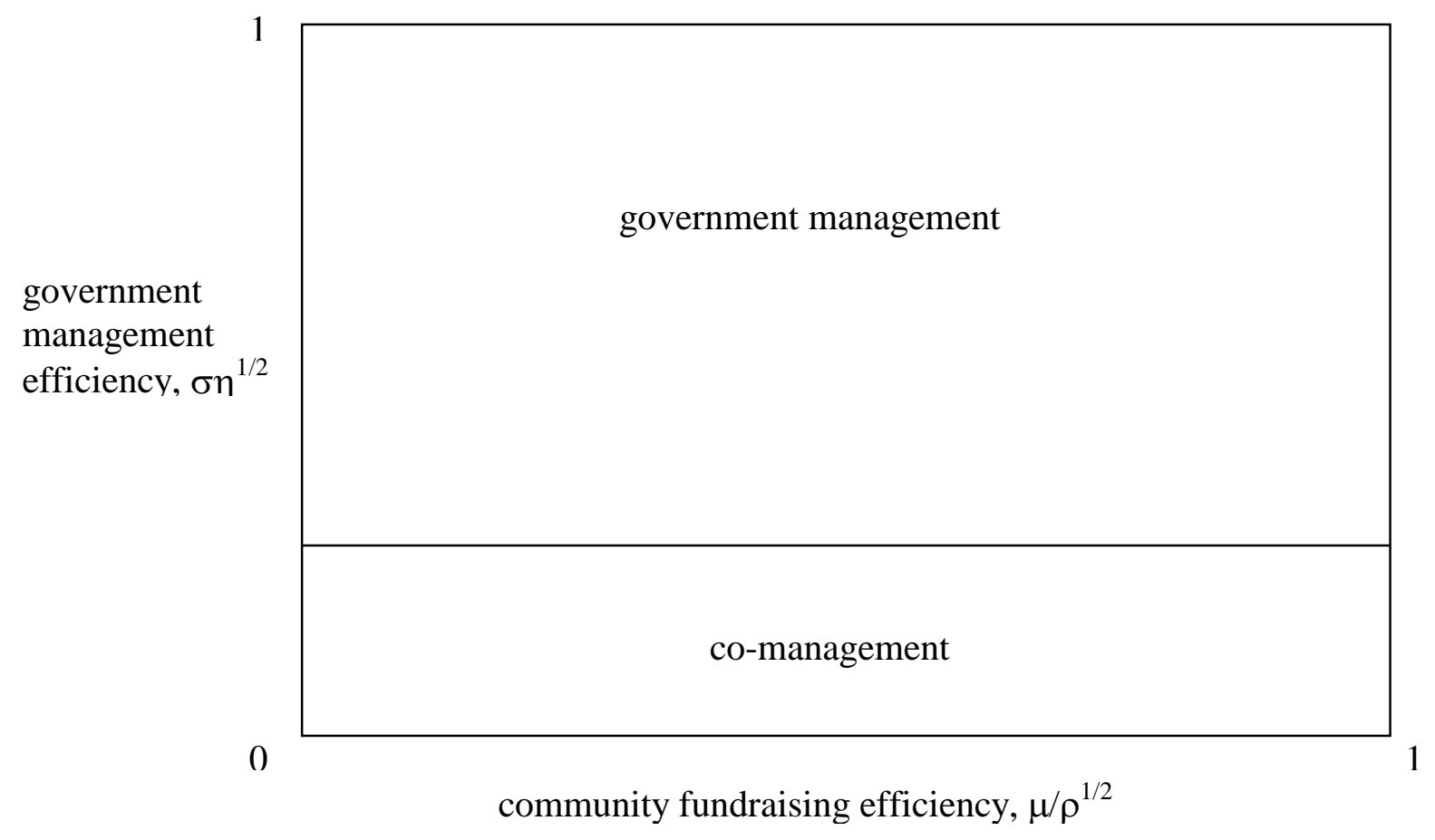


We now consider a change in A. This effectively represents the relative importance the government places on protecting ecosystem quality. At low levels of A, community management prevails. Figure 6 shows that at $A=0.45$, community management covers most of the contract space, with government management only occurring when community is highly inefficient in fundraising. As A increases, the area covered by community management disappears, to be replaced by government management and some co-management. Figure 7 illustrates this result. When government cares relatively little about ecosystem quality, it is less willing to provide conservation management and fundraising labor and turns these responsibilities over to community. As government becomes more interested in providing a high quality of environment, however, it begins taking over these responsibilities, to ensure the level of ecosystem quality it desires. 
Figure 6. Decreasing relative importance of ecosystem to government $(A=0.45)$

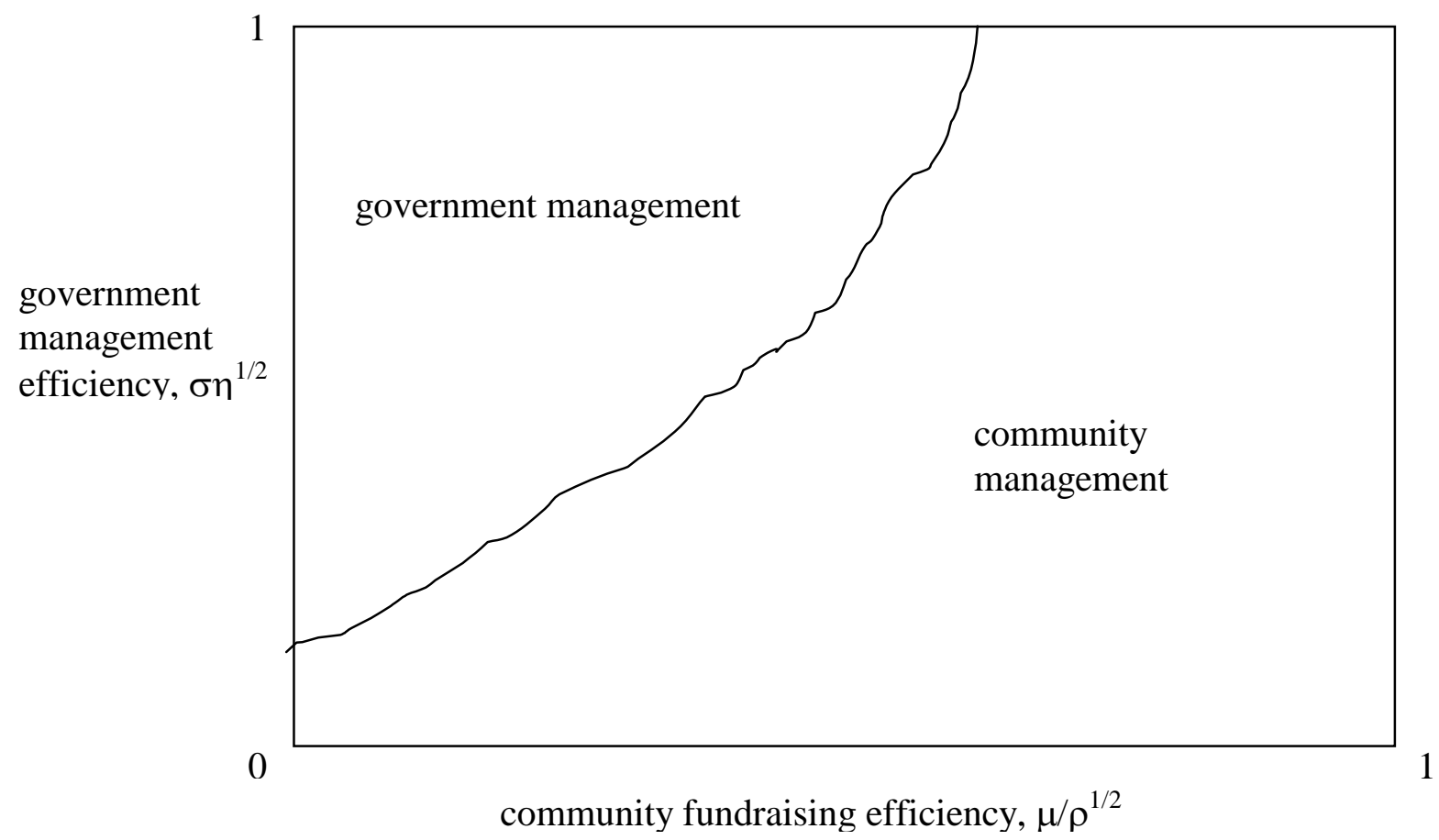

Figure 7. Increasing relative importance of ecosystem to government $(A=1.3)$

\begin{tabular}{|l|}
\hline government \\
management \\
\hline \\
co-management \\
\\
\hline
\end{tabular}


At low levels of $\mathrm{E}_{\mathrm{t}-1}$, the initial quality of the ecosystem, the contract space is mainly divided between community management and government management, with community management prevailing. This can be seen in Figure 8. As $\mathrm{E}_{\mathrm{t}-1}$ increases, however, government management and community management become less prevalent and co-management prevails. Figure 9 shows these results. A possible explanation for this result is that as $\mathrm{E}_{\mathrm{t}-1}$ increases, the gains from specialization become more salient as the ecosystem is more valuable for both parties to protect.

Devolution of state conservation authority and responsibilities should thus not necessarily be taken as a sign of government commitment to conservation, as some CBNRM advocates suggest. As this simple model demonstrates (through the variations in $\mathrm{A}$ and $\mathrm{E}_{\mathrm{t}-1}$ ), it might instead signal state abdication of responsibility due to disinterest. Michael Dove argues that the resources over which communities are granted authority are those resources with no other claimants. He argues that "today's search for 'new' sources of income for 'poor forest-dwellers' is often, in reality, a search for opportunities that have no other claimants - a search for unsuccessful development alternatives" (Dove, 1993). For example, community forestry in Nepal began with the Department of Forests handing over to communities land that was either barren or covered by degraded forests, with the objective of aforestation (Hobley, 1996). Furthermore, devolution may simply be politically or economically attractive to governments by passing on the costs of conservation to the poor in the name of participation and self-help (Hobley, 1996). 
Figure 8. Decreasing initial ecosystem quality $\left(E_{t-1}=1.15\right)$

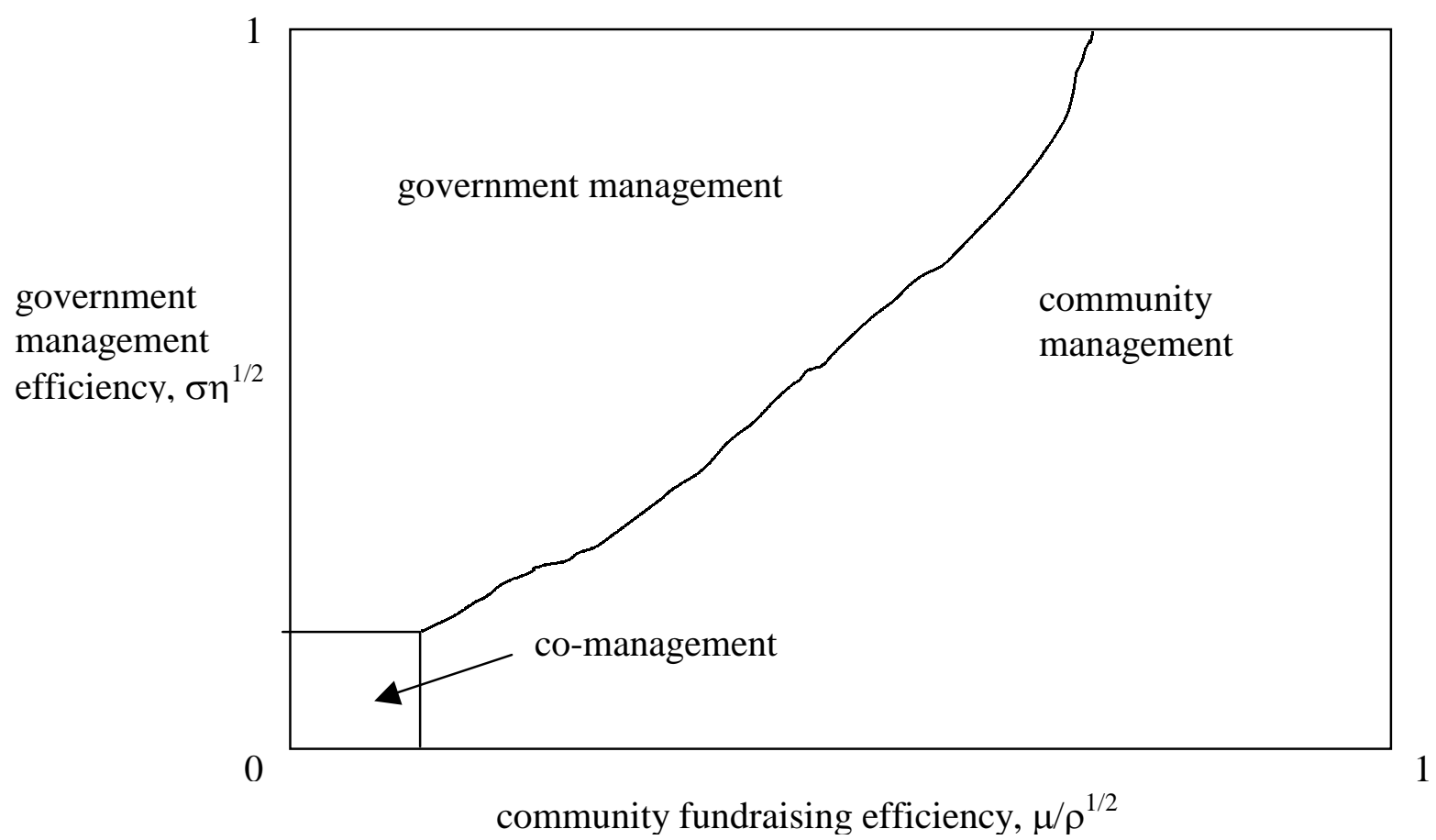

Figure 9. Increasing initial ecosystem quality $\left(E_{t-1}=1.3\right)$

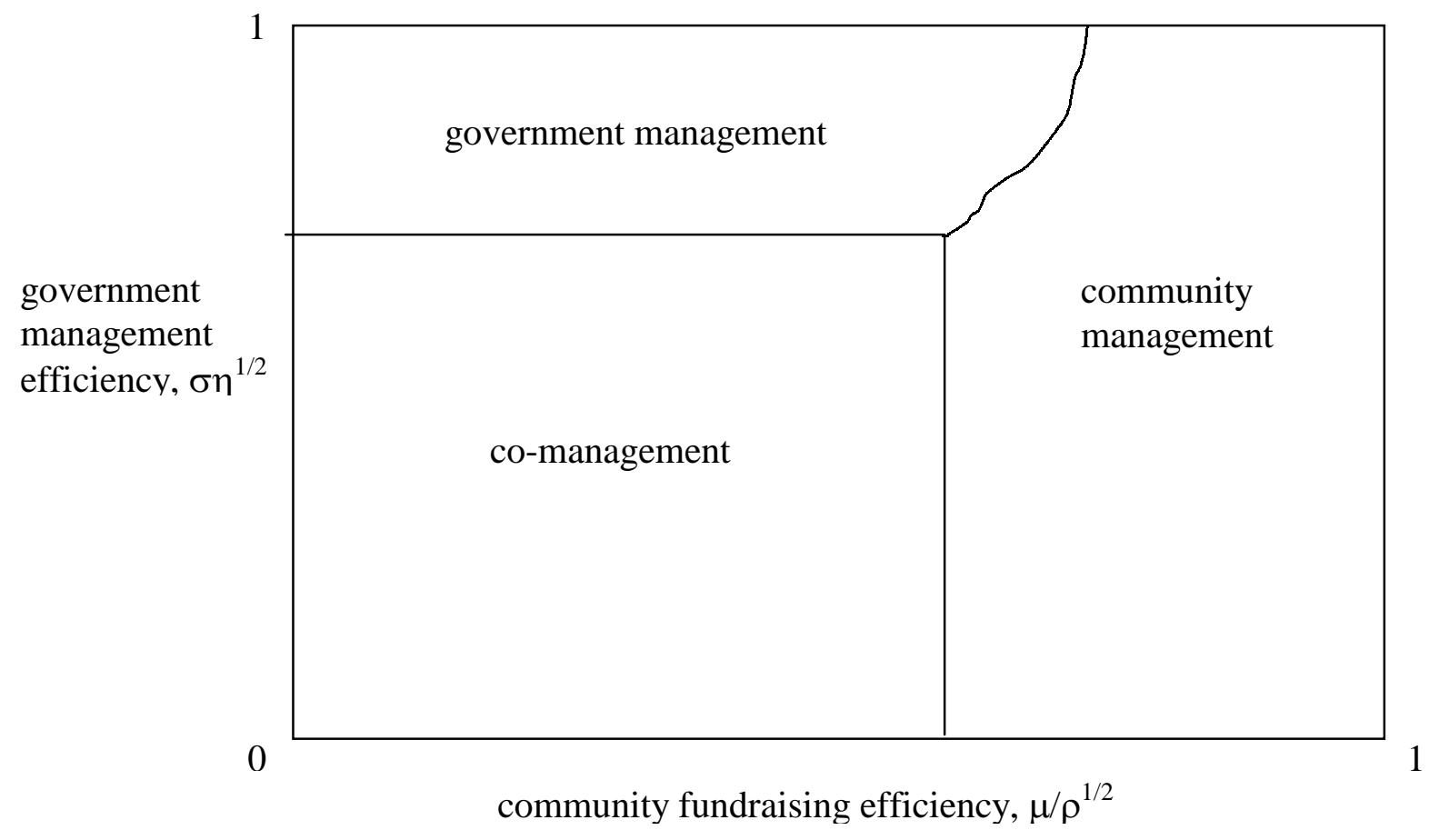


The simulations discussed above illustrate that the optimal contract is sensitive to the model's parameter values, and that the relationships between the parameters and the optimal contracts can be rather complex. Given the relationships in the model, particularly between ecosystem quality and extractive labor, this is to be expected. It also illustrates our original hypothesis that the optimal contract is a function of multiple variables, so that changes in conditions from one site to another will change the optimal conservation contract.

\section{Conclusions}

This paper has illustrated how the choice of optimal conservation contracts, in this case contracts between government and community that allocate fundraising and management labor for conservation, is conditioned by a number of contextual and ability-related variables. We saw that when both agents are relatively efficient in just one of the essential activities for conservation, then specialization, or co-management, is optimal. As the efficiency differences between the parties lessen, it becomes optimal for the other party to undertake both activities and reduce the externality problems associated with co-management. Whether it is optimal to move toward community-based or state-managed conservation depends on the underlying biophysical and socioeconomic context.

This model cautions against a one-size-fits-all approach to conservation management and the current fashion of devolution of management authority and CBNRM and co-management schemes without careful consideration of context. The model provides a possible explanation for why the National Parks system of government forest management may have been effective in the some settings, but not others, and why community-based conservation appears effective in some places and ineffective in others. In this model, the relatively low cohesiveness of U.S. 
communities, combined with high government credibility and fairly large ecosystems of concern, conditions that may not be applicable for other sites of interest, leads government management to be optimal. Applying a similar management regime to a site with high community cohesion and low government credibility, for example, would not be optimal, according to this model. On the other hand, community management such as the aforementioned community forestry scheme in Nepal would most likely be inappropriate for a large high value forest in an area with low community cohesiveness.

The critical relative efficiencies, at which point it becomes optimal to switch from comanagement to government or community management, depend on the values of the other model parameters. For example, we saw that increases in the wage for non-extractive labor leads to switchover to government management at lower levels of government management efficiency than occur at lower wage rates. The same is true for increases in government value of ecosystem quality. Better understanding of these switchover points could improve the choice of conservation contract design for a given site.

Improvements to this model, such as considering intra-community heterogeneity, allowing the community to bargain with the government to arrive at the choice of a contract, and non-linear ecosystem dynamics, may lead to better predictive and prescriptive power, in terms of developing rules of thumb for choosing a conservation contract. But the current model lays out the basic foundation and some useful points of departure. Using empirical cases to both improve the assumptions of the model and to test model predictions may be beneficial. For now, however, this model serves simply to illustrate why the optimal conservation contract may be contextspecific and that neither government management, nor community management, nor comanagement, is appropriate under all conditions. 


\section{References}

Barrett, C.B., K. Brandon, C. Gibson, and H. Gjertsen, "Locating Tropical Biodiversity Conservation Amid Weak Institutions," Working Paper Series in Environmental and Resource Economics WP 99-21, Cornell University (1999).

Bell, C., "A Comparison of Principal-Agent and Bargaining Solutions: The Case of Tenancy Contracts," in: P. Bardhan (ed.), The Economic Theory of Agrarian Institutions (New York: Oxford University Press, 1989).

Berkes, F. and C. Folke, Linking Social and Ecological Systems: Management practices and social mechanisms for building resilience (Great Britain: Cambridge University Press, 1998).

Brandon, K., K. Redford, S. Sanderson, Parks in Peril: People, Politics, and Protected Areas (Washington: Island Press, 1998).

Chakraborty, R.N., I. Freier, F. Kegel, M. Mascher, Community Forestry in the Terai Region of Nepal: Policy Issues, Experience, and Potential (Berlin: German Development Institute, 1997).

Costanza, R., R. d'Arge, R. de Groot, S. Farber, M. Grasso, B. Hannon, K. Limburg, S. Naeem, R. V. O'Neill, J. Paruelo, R.G. Raskin, P. Sutton, M. van den Belt, "The Value of the World's Ecosystem Services and Natural Capital," Nature 387 (1997), 253-260.

Dove, M., “A Revisionist View of Tropical Deforestation and Development," Environmental Conservation 20:1 (1993), 17-24.

Eswaran, M. and A. Kotwal, “A Theory of Contractual Structure in Agriculture," American Economic Review 75:3 (1985), 352.

Getz, W.M., L. Fortmann, D. Cumming, J. du Toit, J. Hilty, R. Martin, M. Murphree, N. OwenSmith, A.M. Starfield, M.I. Westphal, "Sustaining Natural and Human Capital: Villagers and Scientists," Science 283 (1999), 1855-6.

Hardin, G. "The Tragedy of the Commons," Science 162 (1968), 1243-8.

Hobley, M., Participatory Forestry: The Process of Change in India and Nepal (London: Overseas Development Institute, 1996).

Ostrom, E., Governing the Commons: The Evolution of Institutions for Collective Action (United Kingdom: Cambridge University Press, 1990).

Ostrom, E., J. Burger, C.B. Field, R.B. Norgaard, D. Policansky, "Revisiting the Commons: Local lessons, global challenges," Science 284 (1999), 278-282.

Pomeroy, R.S., “Devolution and Fisheries Co-management," unpublished manuscript (1999). 
Rasmussen, L. and R. Meinzen-Dick, "Local Organizations for Natural Resource Management: Lessons from Theoretical and Empirical Literature," EPTD Discussion Paper 11 (Washington, IFPRI Environment and Production Technology Division, 1995).

Soufrière Marine Management Area, http://www.smma.org.lc/TecStuff, accessed May 10, 2000.

Wells, M. and K. Brandon, People and Parks: Linking Protected Area Management with Local Communities (Washington: World Bank, World Wildlife Fund and USAID, 1992).

Western D. and R.M. Wright, Natural Connections: Perspectives in Community-based Conservation (Washington: Island Press, 1992).

World Bank, http://www-esd.worldbank.org/gef/FullProjects.cfm, accessed April 16, 2000. 